\title{
HUBUNGAN TINGKAT KETERDEDAHAN DENGAN TINGKAT KEPUASAN PENDENGAR RADIO KOMUNITAS REMAJA FM KECAMATAN SLIYEG KABUPATEN INDRAMAYU
}

\section{Relationship Between The Level of Comfort With The Level of Satisfaction of Community Radio Listeners}

\author{
Reisha Widia Anggiany ${ }^{1)}$, Hadiyanto ${ }^{2)}$
}

\author{
Departemen Sains Komunikasi dan Pengembangan Masyarakat, Fakultas Ekologi Manusia \\ IPB University, Darmaga Bogor 16680, Indonesia \\ Email: reishaawidiaa@gmail.com ${ }^{1)}$; hadi62@apps.ipb.ac.id ${ }^{2}$
}

\begin{abstract}
This research is motivated by the importance of the role of community radio which is considered quite strategic, inexpensive and simple in providing agricultural information to residents, especially in rural areas. The purpose of this study was to analyze the characteristics of listeners and their relationship with the level of listenership of the Community Radio Youth, to analyze the relationship between the broadcastness of community radio broadcasts and the level of satisfaction of the Youth Community Radio listeners. The study used a survey research method of 50 listeners to the FM Youth community radio using accidental sampling techniques, using the Chi Square statistical test and Spearman Rank. The results of the study showed that the characteristics of respondents who had a negative and significant relationship were age with disability level, namely the frequency of listening, while the frequency and duration of listening to the level of listener satisfaction had a relationship but were not too significant.
\end{abstract}

Keywords: community radio, level of involvement, level of satisfaction

\begin{abstract}
ABSTRAK
Penelitian ini dilatarbelakangi pentingnya peranan radio komunitas yang dinilai cukup strategis, murah dan sederhana dalam memberikan informasi pertanian untuk penduduk khususnya di pedesaan. Tujuan penelitian ini untuk menganalisis karakteristik pendengar dan hubungannya dengan tingkat keterdedahan pendengar Radio Komunitas Remaja FM, menganalisis hubungan keterdedahan siaran radio komunitas dengan tingkat kepuasan pendengar Radio Komunitas Remaja FM. Penelitian menggunakan metode penelitian survei kepada 50 orang pendengar radio komunitas Remaja FM dengan menggunakan teknik accidental sampling, menggunakan uji statistik Chi Square dan Rank Spearman. Hasil dari penelitian menunjukkan bahwa karakteristik responden yang memiliki hubungan yang negatif dan signifikan adalah umur dengan tingkat keterdedahan yaitu frekuensi mendengarkan, sedangkan frekuensi dan durasi mendengarkan dengan tingkat kepuasan pendengar memiliki hubungan tetapi tidak signifikan.
\end{abstract}

Kata kunci: radio komunitas, tingkat keterdedahan, tingkat kepuasan.

\section{PENDAHULUAN}

Perkembangan teknologi komunikasi memberikan pengaruh besar pada aktivitas setiap orang, karena dengan kemudahan yang diberikan oleh teknologi komunikasi memungkinkan setiap orang mampu menjangkau belahan dunia hingga tanpa secara fisik menjangkau belahan dunia tersebut secara langsung. Media komunitas berkembang seiring meningkatnya kesadaran masyarakat mengenai haknya untuk memperoleh informasi yang sesuai dengan kebutuhan. Menurut Gazali (2002), media komunitas merupakan 
lembaga penyiaran yang didirikan untuk melayani komunitas tertentu saja, baik dalam konteks atau batasan geografis maupun dalam konteks rasa identitas atau minat yang sama.

Saat ini, pergeseran industri media ke industri komersial menjadikan media sibuk memenuhi kebutuhan komunitas elite yang lebih menjanjikan keuntungannya secara finansial, sehingga kebutuhan informasi komunitas non-elite terabaikan (Tripambudi 2011). Untuk itu, permintaan mengenai kebutuhan lokal yang belum terpenuhi dapat dimanfaatkan oleh media komunitas yang berkembang saat ini dilingkungan komunitas dengan tujuan yang sama tentu masyarakat desa membutuhkan informasi untuk menambah pengetahuan, wawasan, hiburan dan keterampilan mengenai sumber daya yang terdapat di daerah tempat tinggalnya. Maka dari itu warga desa memerlukan sumber untuk mendapatkan informasi melalui media komunikasi yang membangun.

Lahirnya Undang-undang No. 32 Tahun 2002 tentang Penyiaran menjelaskan perlu dibentuknya sebuah sistem penyiaran yang menjamin terciptanya tatanan informasi nasional yang adil, merata, dan seimbang. Hal tersebut memberikan kesempatan pada media komunitas agar masyarakat di daerah juga dapat berpartisipasi dalam mendirikan lembaga penyiaran yang informasinya sesuai dengan kebutuhan mereka agar dapat memberikan kepuasan. Berdasarkan pengalaman di negara berkembang, komunikasi pembangunan untuk menjangkau masyarakat secara luas, banyak menggunakan media radio dan televisi. Radio merupakan media yang dinilai cukup strategis dalam memberi informasi, pendidikan, dan mengubah perilaku terutama di negara-negara yang penduduknya memiliki penghasilan kecil (Rachmiatie 2007). Oleh karena itu, radio dianggap sebagai media komunikasi yang sederhana dan murah sehingga dapat menjangkau penduduk yang berada di pedesaan.

Dilihat dari fungsinya radio komunitas yang didirikan oleh komunitas tertentu, bersifat independen, dan tidak komersial, bertujuan untuk melayani kepentingan komunitasnya. Oleh karena itu, radio dianggap sebagai media komunikasi yang sederhana dan murah sehingga dapat menjangkau penduduk yang berada di pedesaan. Menurut Sudibyo (2004), radio komunitas merujuk pada stasiun penyiaran radio yang didirikan oleh dan untuk komunitas tertentu, yang tidak bersifat komersial dan muatannya sebagian besar tentang dinamika dan kebutuhan komunitas itu sendiri.

Menurut Mckay seperti dikutip Atika (2013) mengatakan bahwa di Afrika radio komunitas sangat efektif menjangkau petani kecil di seluruh pelosok. Program radio dapat mendorong komunitas merumuskan masalah dan menemukan solusi lokal. Selain itu, program siaran radio tersebut disesuaikan dengan komunitas yang dituju, seperti menggunakan bahasa lokal sesuai dengan bahasa yang dipakai anggota komunitasnya di setiap tempat atau daerah, radio komunitas mempunyai latar belakang budaya dan historis yang berbeda. Konten yang diberikan radio komunitas hanya berisi tentang lingkungan sebuah komunitas pedesaan yang berperan sebagai media penyuluhan dalam berbagai bidang seperti pendidikan, kesehatan atau bahkan pertanian untuk komunitas yang ada di desa tersebut. Sehingga, radio komunitas tidak hanya berfungsi sebagai media komunikasi tetapi juga bisa menjadi media yang sangat berpengaruh bagi komunitas tersebut termasuk dalam hal pendidikan, kesehatan dan bahkan pertanian.

Fraser dan Estrada (2001) juga mengemukakan bahwa radio komunitas merupakan sebuah pelayanan nonprofit yang dimiliki dan dikelola oleh komunitas tertentu. Pengelolaan Radio Komunitas Remaja FM harus sesuai dengan prinsip media komunitas, yaitu "dari, oleh, dan untuk komunitas". Radio komunitas diharapkan dapat eksis sebagai lembaga penyiaran yang diperuntukan kepada pemenuhan kebutuhan masyarakat local. Hal tersebut dapat dicapai ketika keberadaan radio komunitas dapat dimanfaatkan dengan baik oleh anggota komunitas selaku pendengar yang turut andil dalam terbentuknya radio komunitas tersebut.

Hadirnya Radio Komunitas Remaja FM merupakan salah satu contoh dari radio komunitas pedesaan di Desa Majasari, Kecamatan Sliyeg, Kabupaten Indramayu ini telah mengudara sejak tahun 2008. Terbentuknya radio ini berawal dari keinginan para petani yang membutuhkan informasi seputar pertanian tanpa harus mengganggu waktu kerja mereka. Pengelolaan Radio Komunitas Remaja FM harus sesuai dengan prinsip media komunitas, yaitu "dari, oleh, dan untuk komunitas".

Salah satu penelitian tentang tingkat keterdedahan dan tingkat kepuasan terhadap radio komunitas telah 
dilakukan oleh Silviana (2015). Penelitian tersebut dilakukan terhadap pendengar Radio Komunitas ROne FM yang mengungkapkan bahwa pendengar sebagai warga komunitas yang memiliki keterdedahan pada siaran radio tidak sepenuhnya berhubungan dengan tingkat kepuasan pendengar radio komunitas. Hal tersebut karena keterdedahan yang berhubungan dengan tingkat kepuasan pendengar tergantung pada masing-masing individu dan keterdedahannya terhadap radio komunitas.

Oleh karena itu, penelitian ini juga untuk menggali lebih dalam lagi mengenai hubungan antara karakteristik responden dengan keterdedahan, dan hubungan antara keterdedahan dengan kepuasan pendengar Radio Komunitas Remaja FM itu sendiri. Mengingat betapa pentingnya peranan Radio Komunitas sebagai media komunikasi untuk kebutuhan masyarakat terutama warga desa dalam mengkomunikasikan pesan-pesan pembangunan atau penyuluhan dalam berbagai bidang seperti pendidikan, kesehatan dan pertanian kepada masyarakat. Maka masalah tersebut mendorong peneliti untuk melakukan penelitian terhadap Radio Komunitas Remaja FM. Penelitian ini dikemas dalam judul: Keterdedahan dan kepuasan pengengar Radio Komunitas Remaja FM.

Bertitik tolak dari latar belakang masalah, maka yang menjadi pokok dalam pembahasan penelitian ini dirumuskan sebagai berikut:

1. Bagaimanakah karakteristik pendengar Radio Komunitas Remaja FM?

2. Bagaimanakah tingkat keterdedahan pendengar Radio Komunitas Remaja FM?

3. Bagaimanakah tingkat kepuasan pendengar Radio Komunitas Remaja FM?

4. Bagaimanakah hubungan karakteristik pendengar dengan tingkat keterdedahan siaran radio komunitas Remaja FM? Dan Bagaimanakah hubungan tingkat keterdedahan dengan tingkat kepuasan pendengar Radio Komunitas Remaja FM?

Secara umum penelitian ini bertujuan untuk menganalisis sejauh mana hubungan peran radio komunitas sebagai media penyuluhan pengetahuan dan keterampilan petani di Desa Majasari, dan secara khusus yang menjadi tujuan penelitian adalah:
1. Mendeskripsikan karakteristik pendengar Radio Komunitas Remaja FM.

2. Mendeskripsikan tingkat keterdedahan pendengar Radio Komunitas Remaja FM.

3. Mendeskripsikan tingkat kepuasan pendengar Radio Komunitas Remaja FM.

4. Menganaslisis hubungan kerakteristik pendengar dengan tingkat keterdedahan pendnegar Radio Komunitas Remaja FM dan Menganalisis hubungan tingkat keterdedahan siaran radio komunitas dengan tingkat kepuasan pendengar Radio Komunitas Remaja FM.

\section{PENDEKATAN TEORITIS}

\section{Radio Komunitas}

Stasiun penyiaran komunitas dalam UU No. 32/2002 Pasal 21 adalah lembaga penyiaran yang berbentuk badan hukum Indonesia, didirikan oleh komunitas tertentu, bersifat independen dan tidak komersial dengan daya pancar rendah, luas jangkauan wilayahnya terbatas, serta untuk melayani kepentingan komunitasnya. Secara umum, radio komunitas adalah dari komunitas, oleh komunitas, untuk komunitas, dan tentang komunitas.

Seperti disebutkan dalam Undang-Undang Penyiaran no 32 tahun 2002, bahwa radio komunitas merupakan bagian dari sistem penyiaran atau lembaga penyiaran yang didirikan secara swadaya oleh sekolompok orang atau komunitas tertentu.Istilah radio komunitas merujuk pada pemilikan dan wilayah orientasi yang melokal sebagai antitesis radio swasta yang meluas dan berjaringan. Istilah ini kemudian lebih sering dipakai karena dirasa santun dan akrab secara internasional (Ismahfudi, 2007).

Tipologi yang akan diteliti lebih fokus pada jenis radio berbasis komunitas, yaitu Radio Komunitas Remaja FM. Jenis tersebut dipilih karena melihat perkembangan radio komunitas yang dilakukan oleh warga dilingkungan desa yang terletak didaerah Sliyeg, Kabupaten Indramayu. Berdasarkan pengertian yang dikemukakan beberapa sumber, pada dasarnya pengertian radio komunitas memiliki kesamaan, yaitu radio komunitas yang didirikan oleh anggota komunitas, dikelola oleh mereka, dan program acaranya ditujukan untuk memenuhi kepentingan 
mereka. Radio Komunitas Remaja FM adalah salah satu radio yang menempati wilayah geografis tertentu, yaitu di Kecamatan Sliyeg.

\section{Keterdedahan pada Radio Komunitas}

Rubin (2005) mengartikan terpaan media sebagai suatu aktivitas khalayak dalam memanfaatkan atau menggunakan media yang mengacu pada utilitas, intensionalitas, selektivitas, dan keterlibatan khalayak dengan media. Aspek keterdedahan dapat diukur berdasarkan:

(1) Waktu yang digunakan dalam mengikuti berbagai informasi menggunakan media.

(2) Jenis-jenis isi media yang diikuti.

(3) Hubungan yang terdapat antara individu yang mengkonsumsi informasi baik dengan isi media maupun dengan media.

Menurut De Fleur seperti dikutip Atika (2013) mengungkapkan bahwa keterdedahan atau pola penggunaan media massa merupakan total waktu ratarata yang digunakan dalam sehari, frekuensi, dan pilihan acara. Singkatnya, keterdedahan adalah terpaan khalayak terhadap satu atau beberapa pesan dari media komunikasi salah satunya radio. Berdasarkan hasil penelitian Dewi (2011), Tede (2012), dan Nurmayanti (2012) dapat dirumuskan aspek yang dapat dijadikan indikator keterdedahan terhadap siaran radio dapat dilihat dari frekuensi dan lama khalayak mendengarkan siaran radio. Hasil penelitian Tede (2012) menyatakan karakteristik pendengar yang berpengaruh terhadap keterdedahannya pada siaran radio adalah kepemilikan media massa terhadap lama mendengarkan. Semakin sering frekuensi mendengar radio, semakin besar kemungkinan khalayak untuk mendengarkan berbagai siaran radio. Pada penelitian ini keterdedahan pada siaran radio merupakan keterlibatan pendengar radio komunitas dalam mendengarkan siaran radio komunitas yang diukur melalui tiga indikator, yaitu: frekuensi mendengar, durasi atau lama mendengarkan, dan pilihan acara yang dipilih oleh pendengar.

\section{Kepuasan Komunitas}

Dominick (2002) mengklasifikasikan kebutuhankebutuhan (needs) terhadap penggunaan media menjadi empat, yaitu 1) Cognition (dorongan memperoleh informasi), 2) Diversion (dorongan meliputi bentuk stimuli, relaksasi, dan pelepasan emosi), 3) Sosial utility (dorongan meliputi kebutuhan kontak sosial dalam lingkungan sosial), 4) Withdrawal (kebutuhan melepaskan diri dari aktivitas-aktivitas tertentu dan bukan sekedar relaksasi saja). Berdasarkan pada hasil penelitian sebelumnya, menurut Atika (2013), pemenuhan kebutuhan informasi melalui radio komunitas di Radio Remaja FM tergolong rendah sedangkan di Radio Whisnu tergolong sangat tinggi. Hal tersebut dipengaruhi oleh faktor yang berhubungan nyata dengan tingkat pemenuhan kebutuhan informasi petani melalui radio komunitas adalah frekuensi mendengarkan dan durasi mendengarkan radio komunitas. Dewi (2011) menunjukkan bahwa efek yang dirasakan masyarakat lokal adalah peningkatan pengetahuan dan informasi setelah mendengarkan tips maupun informasi yang disampaikan oleh radio komunitas Angkringan dan Lintas Merapi yang berada di Yogyakarta. Secara sederhana, radio komunitas diartikan sebagai radio dari, oleh, untuk, dan tentang komunitas. Radio ini menjadikan komunitas sebagai basis operasionalisasi radio. Keberadaan radio komunitas dapat menyuarakan berbagai aspirasi, keluh-kesah, persoalanberbagai peristiwa lokal dengan menyentuh kehidupan nyata masyarakat komunitasnya menjadi wadah sekaligus fasilitator serta memberikan advokasi atas berbagai isu lokal masyarakat. Hal-hal tersebut yang dinilai dapat memberikan kepuasan atas terpenuhi kebutuhanmereka melalui radio komunitas.

\section{Karakteristik Responden}

\section{Umur}

Umur adalah lama hidup pengguna media sosial pada saat penelitian dilakukan yang dihitung sejak hari kelahiran yang dinyatakan dalam satuan tahun. Dalam penelitian ini, umur diukur menggunakan standar deviasi dan terbagi menjadi dua kategori yaitu dewasa muda $(<43$ tahun), dewasa pertengahan(44-54 tahun) dan dewasa tua( $>54$ tahun).

\section{Pendidikan}

Menurut Badan Pusat Statistik, pendidikan terdiri atas pendidikan formal dan pendidikan nonformal. Pendidikan formal adalah jalur pendidikan yang terstruktur dan berjenjang yang terdiri atas pendidikan dasar, pendidikan menengah, dan pendidikan tinggi, meliputi SD/MI/Sederajat, SMP/MTs/Sederajat, 
SMA/MA/Sederajat dan Perguruan Tinggi. Pendidikan orang tua yang dimaksud disini ialah pendidikan formal yang telah dijelaskan oleh UndangUndang di atas dan juga pendidikan informal yang tidak bisa diabaikan. Pendidikan formal orang tua biasanya sangat erat kaitannya dengan kondisi keuangan yang mereka miliki. Seseorang yang memiliki banyak uang cenderung untuk termotivasi melanjutkan pendidikan ke tingkat yang lebih tinggi lagi. Namun, seringkali yang terjadi di pedesaan ialah keterbatasan keuangan yang menyebabkan banyak orang tua tidak melanjutkan pendidikan formal mereka.

\section{Jenis Pekerjaan}

BPS dengan buku Klasifikasi Baku Jenis Pekerjaan Indonesia (2002) memaparkan bahwa pekerjaan adalah suatu rangkaian tugas yang dirancang untuk dikerjakan oleh satu orang dan sebagai imbalan diberikan upah dan gaji menurut kualifikasi dan berat ringannya pekerjaan tersebut. Sedangkan status pekerjaan adalah jenis kedudukan seseorang dalam pekerjaan, status tersebut diklasifikasikan dalam (1) berusaha sendiri tanpa rekan kerja; (2) berusaha sendiri dibantu oleh anggota keluarga; (3) pengusaha dengan pekerja tetap; (4) karyawan; dan (5) pekerja tidak dibayar. Kemudian, jenis pekerjaan adalah macam pekerjaan yang dilakukan oleh seseorang atau ditugaskan kepada seseorang yang sedang bekerja atau yang sementara tidak bekerja. ini nantinya juga biasa diklasifikasikan berdasarkan tingkat keahlian dan spesialisasi keahlian. Jenis pekerjaan sendiri terdiri dari sektor formal yang memiliki penghasilan tetap dan informal yang memiliki penghasilan tidak tetap.

\section{Kerangka Pemikiran}

Karakteristik responden sebagai pendengar radio komunitas terdiri atas umur, tingkat pendidikan, jenis pekerjaan, dan kepemilikan media massa. Akses terhadap radio komunitas terdiri atas jumlah waktu yang dialokasikan untuk mendengarkan materi dari radio komunitas tersebut. Variabel keterdedahan radio komunitas merujuk pada tiga alat ukur yang dikemukakan oleh De Fleur seperti dikutip Atika (2013), yaitu total waktu rata-rata yang digunakan dalam sehari, frekuensi, dan pilihan acara. Alasan dalam mendengarkan radio komunitas diduga berhubungan dengan frekuensi dan durasi pendengar mendengarkan radio itu tentu berbeda setiap individu tergantung dari apa yang mereka ingin dengarkan. Lebih lanjut, mendengarkan radio berkaitan dengan tingkat kepuasan yang dirasakan pengguna yang sesuai dengan tujuan apa yang mendasarinya mendengarkan siaran tersebut. Variabel efek dari penggunaan media massa dapat dioperasionalkan sebagai evaluasi media massa, khususnya radio komunitas, dalam memberi kepuasan pada pendengarnya. Kepuasan atas terpenuhinya kebutuhan pendengar yang meliputi pemenuhan kebutuhan informasi dan kontak sosial yang diperoleh melalui radio komunitas yang dikemukakan oleh Dominick (2002).

Hubungan karakteristik pendengar dengan keterdedahan terhadap radio komunitas dan tingkat kepuasan setelah mendengarkan siaran radio komunitas yang tersaji pada Gambar 1 .

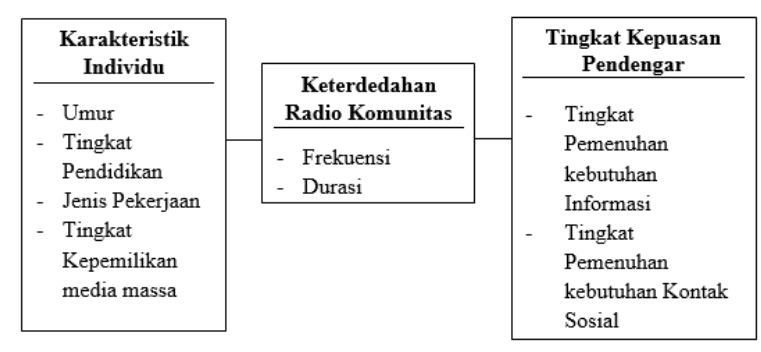

Gambar 1 Kerangka Pemikiran

\section{METODE PENELITIAN}

Penelitian ini menggunakan metode kuantitatif yang didukung dengan data kualitatif. Metode kuantitatif digunakan untuk menjawab pertanyaan mengenai keterdedahan pendengar dalam mendengarkan Radio Komunitas Remaja FM, durasi dan frekuensi mendengarkan radio yang berkaitan dengan jumlah dan lamanya waktu yang diluangkan, serta tingkat kepuasan yang diperoleh pendengar setelah mendengarkan Radio Komunitas Remaja FM. Data kuantitatif diperoleh dengan menggunakan instrumen kuesioner. Data kualitatif digunakan untuk memperkuat data kuantitatif. Pengambilan data kualitatif dilakukan dengan wawancara mendalam (indepth interview) menggunakan panduan pertanyaan kepada para informan.

Pendekatan utama yang digunakan adalah pendekatan kuantitatif dengan metode survei. Menurut Singarimbun dan Effendi (2014), penelitian survei 
adalah penelitian yang mengambil sampel dari satu populasi dan menggunakan kuesioner sebagai alat pengumpulan data yang pokok. Penelitian ini dimaksudkan sebagai penelitian penjelasan (explanatory research), karena data yang diperoleh digunakan untuk menjelaskan hubungan kausal antar varibel melalui pengujian hipotesis.

Radio komunitas yang dipilih untuk penelitian ini adalah Radio Komunitas Remaja FM yang terletak di Desa Majasari, Kecamatan Sliyeg, Kabupaten Subang. Radio komunitas ini dipilih secara sengaja (purposive) dengan pertimbangan beberapa hal diantaranya: 1) Radio Komunitas Remaja FM merupakan stasiun radio komunitas yang didirikan oleh masyarakat sekitar, yaitu warga desa setempat dengan tujuan untuk memenuhi kebutuhun komunitasnya. 2) Radio Komunitas Remaja FM sudah berdiri cukup lama, yaitu sejak tahun 2007. 3) Radio Komunitas Remaja FM tergolong radio yang aktif dan masih mengembangkan program siaran dikomunitasnya sampai saat ini. Lokasi yang menjadi sasaran penelitian adalah Desa Majasari, Kecamatan Sliyeg, Kabupaten Subang. Penentuan lokasi dilakukan secara sengaja (purposive) dengan pertimbangan bahwa lokasi Desa Majasari bersamaan dengan lokasi Radio Komunitas Remaja sehingga terjangkau oleh sinyal siaran yang dipancarkan Radio Komunitas Remaja. Berdasarkan pertimbangan tersebut, perlu diamati karakteristik, keterdedahan, dan kepuasan pendengar di Radio Komunitas Remaja FM. Kegiatan penelitian ini dilaksanakan dalam jangka waktu satu bulan yang terdapat pada Lampiran 2, terhitung mulai bulan Juli 2017 sampai dengan Agustus 2017.

Data yang digunakan dalam penelitian ini adalah data primer dan data sekunder. Data primer didapatkan langsung di lapang dengan cara wawancara menggunakan kuesioner, observasi dan wawancara mendalam menggunakan panduan wawancara. Sementara itu, data sekunder diperoleh melalui studi literatur dan informasi tertulis yang dapat digunakan dan sesuai dengan topik penelitian.

Pemilihan responden pada penelitian ini dilakukan menggunakan pengambilan accidental sampling. Unit analisis dalam penelitian ini adalah pendengar Radio Komunitas Remaja FM. Responden pada penelitian ini diambil sebanyak 50 orang. Responden adalah pendengar Radio Komunitas Remaja FM dan mendengarkan program siaran yang diadakan radio komunitas tersebut terhadap usaha atau kegiatan pertaniannya. Selain responden, juga diperlukan informan yang memberikan informasi untuk melengkapi data penelitian. Informan dalam penelitian ini meliputi pihak pengelola Radio Komunitas Remaja FM.

Data kuantitatif diolah menggunakan aplikasi Microsoft Excel 2010 dan SPSS. Pembuatan tabel frekuensi, grafik, diagram, serta tabel tabulasi silang untuk melihat data awal responden untuk masingmasing variabel secara tunggal menggunakan aplikasi Microsoft Excel 2010. Kemudian SPSS version 24.0 digunakan untuk membantu dalam uji statistik yang akan menggunakan uji regresi.

\section{HASIL DAN PEMBAHASAN}

\section{Profil Desa Majasari}

Desa Majasari merupakan sebuah desa yang terletak di Kecamatan Sliyeg, Kabupaten Indramayu, Jawa Barat. Wilayah Desa Majasari sebelah utara berbatasan dengan Desa Majasih, sebelah timur berbatasan dengan Desa Sliyeg, sebelah barat berbatasan dengan Desa Sleman Lor, dan sebelah selatan berbatasan dengan Desa Tambi Lor. Jarak yang ditempuh untuk mencapai Desa Majasari adalah $1 \mathrm{Km}$ bila ditempuh dari Kecamatan Sliyeg. Selanjutnya jarak yang ditempuh dari ibukota Kabupaten/Kota adalah sejauh $20 \mathrm{Km}$.

Kondisi bangunan perumahan di wilayah ini pun tergolong cukup padat dan jarak antara satu rumah lainnya cukup berdekatan. Selain itu, bentuk pemukiman warga seperti tersentral/mengumpul. Hal ini disebabkan oleh Desa Majasari dikelilingi oleh lahan persawahan.

Luas wilayah Desa Majasari, Kecamatan Sliyeg, Kabupaten Indramayu adalah 293,09 hektare. Kondisi bentangan wilayah yang ada di Desa Majasari tergolong wilayah dataran rendah. Lahan dimanfaatkan untuk berbagai kebutuhan, seperti tanah sawah dengan luas sekitar 201,04 ha, pemukiman seluas 35,16 ha, dan perkebunan seluas 17,19 ha. Dilihat dari data monografi desa, menunjukkan bahwa sebagian besar bahkan seluruhnya digunakan di dataran rendah. 


\section{Karakteristik Responden}

\section{Umur Responden}

Berdasarkan hasil penelitian, diketahui bahwa selang umur responden berkisar antara 43 sampai lebih dari 54 tahun. Usia responden paling muda 43 tahun dan responden paling tua berusia 75 tahun. Peneliti mengkategorikan umur menggunakan standar deviasi dan terbagi menjadi tiga kategori yaitu dewasa muda $(<43$ tahun), dewasa pertengahan(44-54 tahun) dan dewasa tua( $>54$ tahun).

Tabel 1 Jumlah dan persentase responden berdasarkan umur

\begin{tabular}{lcc}
\hline \multicolumn{1}{c}{ Umur } & $\mathrm{n}$ & $\%$ \\
\hline Dewasa Muda $\leq$ 43 Tahun & 16 & 32 \\
Dewasa Pertengahan 44-54 Tahun & 18 & 36 \\
Dewasa Tua $>$ 54 Tahun & 16 & 32 \\
\hline \multicolumn{1}{c}{ Jumlah } & 50 & 100 \\
\hline
\end{tabular}

Dari tabel di atas maka dapat diketahui bahwa responden berumur 44 sampai 54 tahun yaitu sebesar $36 \%$. Persentase yang sama ialah responden kelompok umur 28 sampai 43 tahun dan kelompok umur lebih dari 54 tahun yaitu masing-masing memiliki nilai 32\%. Hal ini signifikan bahwa pendengar Radio Komunitas Remaja FM didominasi oleh kelompok umur antara 28 sampai 43 dan sampai lebih dari 54 tahun. Responden yang berada dalam umur ini umumnya adalah warga yang telah lama mendengarkan Radio Komunitas Remaja FM yaitu sejak tahun 2008, meski terdapat beberapa warga juga yang baru mulai mendengarkan Radio Komunitas Remaja FM pada tahun 2010 keatas. Sebagaimana data umur responden yang dikumpulkan, 28 tahun paling rendah dan 75 tahun paling tinggi. Seluruh responden merupakan pendengar aktif Radio Komunitas Remaja FM dengan alasan ingin mempererat tali silaturahmi, mencari informasi mengenai desa, pertanian dan hiburan selagi mengisi waktu disela-sela waktu bertani dan waktu istirahat.

\section{Tingkat Pendidikan Responden}

Tingkat pendidikan adalah jenjang terakhir sekolah formal yang pernah diikuti oleh pendengar radio yang dipilih sebagai responden sampai dengan waktu saat penelitian berlangsung. Tingkat pendidikan pada penelitian ini dibagi menjadi lima golongan yaitu Tidak Lulus SD, Lulus SD/Sederajat, Lulus
SMP/Sederajat, Lulus SMA/Sederajat, dan Tamatan Diploma.

Tabel 2 Jumlah dan persentase responden berdasarkan tingkat pendidikan

\begin{tabular}{ccc}
\hline Pendidikan Terakhir & $\mathrm{n}$ & $\%$ \\
\hline Tidak Lulus SD & 2 & 4 \\
Lulus SD/Sederajat & 23 & 46 \\
Lulus SMP/Sederajat & 21 & 42 \\
Lulus SMA/Sederajat & 2 & 4 \\
Tamatan Diploma & 1 & 2 \\
\hline Jumlah & 50 & 100 \\
\hline
\end{tabular}

Berdasarkan Tabel 2 Tingkat Pendidikan responden yang ada di Desa Majasari masih relatif rendah. Hal ini dikarenakan tingkat pendidikan terakhir responden didominasi oleh responden yang tamat SD yaitu sebesar $46 \%$. Responden yang tamat SMP sebesar $42 \%$. Responden yang tamat SMA sebesar $4 \%$. Selain itu ada pula responden yang tidak mengenyam bangku pendidikan atau tidak lulus sekolah dasar sebesar 4\%. Kebanyakan dari mereka yang tamat SD menjadi petani dan ibu rumah tangga. Mereka memutuskan bekerja setelah tamat sekolah untuk membantu ekonomi keluarga.

“..pendengar radione emang kebanyakan ya bapakbapak sama ibu-ibu yang sekolahnya Cuma sampe SD mbak. Banyak dari mereka yang dulunya ya habis lulus SD ya bantuin orang tuane di sawah. Jadi sekarang juga pada jadi petani.." (PK, laki-laki, 54 tahun)

\section{Jenis Pekerjaan}

Jenis pekerjaan adalah mata pencaharian yang dikerjakan responden di Desa Majasari untuk memenuhi kebutuhan hidupnya. Jenis pekerjaan di pada penelitian ini dibagi menjadi enam pekerjaan yaitu Buruh, Pelajar/Mahasiswa, Wirausaha, PNS/Guru, Petani, dan Ibu Rumah Tangga.

Berdasarkan Tabel 3 jenis pekerjaan responden yang ada di Desa Majasari di dominasi oleh petani yakni sebesar 40\%. Hal ini dikarenakan mayoritas penduduk Desa Majasari bermatapencaharian sebagai petani. Mayoritas kedua adalah wirausaha atau pedagang yg menjual hasil pertanian yaitu sebesar $36 \%$. 
Tabel 3 Jumlah dan persentase responden berdasarkan jenis pekerjaan

\begin{tabular}{ccc}
\hline Jenis Pekerjaan & $\mathrm{n}$ & $\%$ \\
\hline Buruh & 5 & 10 \\
Pelajar/Mahasiswa & 0 & 0 \\
Wirausaha & 18 & 36 \\
PNS/Guru & 2 & 4 \\
Petani & 20 & 40 \\
Ibu Rumah Tangga & 5 & 10 \\
\hline Jumlah & 50 & 100 \\
\hline
\end{tabular}

\section{Kepemilikan Media Massa}

Tingkat kepemilikan media massa yang digolongkan pada tabel ini, ialah segala keterangan responden dalam memiliki macam media massa. pada kategori rendah hanya memiliki salah satu dari macam media masa, sedangkan pada kategori sedang memiliki dua sampai dengan tiga macam media masa, selanjutnya pada kategori tinggi memiliki banyak macam media masa diantaranya ialah: Memiliki Televisi, radio, surat kabar, majalah, dan dapat mengakses jaringan internet.

Tabel 4 Jumlah dan persentase responden berdasarkan tingkat kepemilikan media massa

\begin{tabular}{ccc}
\hline Kepemilikan Media Massa & $\mathrm{n}$ & $\%$ \\
\hline Rendah & 12 & 24 \\
Sedang & 34 & 68 \\
Tinggi & 4 & 8 \\
\hline Jumlah & 50 & 100 \\
\hline
\end{tabular}

Dari Tabel 4 maka dapat diketahui tingkat kepemilikan media massa responden yang ada di Desa Majasari masih relatif rendah. Responden yang memiliki media massa satu jenis atau kategori rendah mencapai $24 \%$, Responden dengan kepemilikan media massa berjumlah dua jenis atau dalam kategori sedang mencapai $68 \%$, sedangkan responden dengan kepemilikan media massa berjumlah tiga jenis atau lebih dalam kategori tinggi mencapai $8 \%$. Hal ini signifikan Mereka lebih banyak menggunakan media masa radio dan televisi untuk media informasi dan hiburan. Hal ini ditegaskan seperti yang tertera pada data yang telah diperoleh hasil wawancara, seorang narasumber mengungkapkan bahwa warga Desa Majasari memang kurang terdedah oleh media internet.

\section{Frekuensi Mendengarkan}

Frekuensi mendengarkan radio komunitas pada penelitian ini merujuk pada berapa kali dalam satu minggu seorang pendengar mendengarkan Radio Komunitas Remaja FM. Berapa kali mendengarkan radio komunitas menunjukkan seberapa aktif pendengar mendengarkan siaran radio komunitas ini dan seberapa besar manfaat yang telah didapatkan oleh pendengar. Berdasarkan hasil yang diperoleh, skor tertinggi yang diperoleh adalah 7 , artinya responden mendengarkan radio komunitas selama 7 hari atau setiap hari dalam satu minggu. Adapun skor terendah adalah 1 hari selama satu minggu. Terdapat tiga kategori tinggi, apabila jumlah skor berkisar antara 5 hingga 7 hari per satu minggu. Kemudian sedang, apabila jumlah skor berkisar antara 3 hingga 4 hari per satu minggu dan rendah apabila jumlah skor berkisar antara 1 hingga 2 hari per satu minggu. Jumlah dan persentase pendengar Radio Komunitas Remaja FM berdasarkan frekuensi tersaji pada Tabel 5 .

Tabel 5 Jumlah dan persentase responden berdasarkan frekuensi mendengarkan radio

\begin{tabular}{lccc}
\hline Frekuensi & Hari/Minggu & $\mathrm{n}$ & $\%$ \\
\hline Rendah & 1-2/minggu & 4 & 8 \\
Sedang & 3-4/minggu & 16 & 32 \\
Tinggi & 5-7/minggu & 30 & 60 \\
\hline Jumlah & 9-13/4 minggu & 50 & 100 \\
\hline
\end{tabular}

Dari Tabel 5 dapat diketahui bahwa mayoritas responden di Desa Majasari masih mendengarkan radio dalam kesehariannya. Sebanyak $60 \%$ responden yang mendengarkan radio hampir setiap hari, dan $32 \%$ responden mendengarkan radio masing-masing antara 3-4 hari dalam satu minggu dan sisanya, sebanyak $8 \%$ responden mendengarkan radio hanya 1-2 hari dalam satu minggu.

Frekuensi mendengarkan radio komunitas di Desa Majasari terbilang tinggi karena kebanyakan warganya mendengarkan radio hampir sepanjang hari. Hal ini Seperti yang diungkapkan oleh salah satu responden sebagai berikut:

"Bapak kalo dengerin radio gak setiap hari mbak, paling hari senin, rabu, jum'at Bapak denger seharian soalnya cuma hari itu yang ada berita tentang pertanian sama harga pasar. Kalo hari lain paling dengar hiburannya saja mbak" (W, laki-laki, 57 tahun). 


\section{Durasi Mendengarkan}

Durasi mendengarkan radio adalah intensitas lamanya responden mendengarkan radio komunitas yang dihitung dalam satuan berapa jam dalam satu hari. Aktivitas mendengarkan radio komunitas dilihat dari seberapa lama waktu yang dibutuhkan oleh responden untuk menyalakan radio, seberapa lama waktu yang dibutuhkan responden untuk mendengarkan dan bertanya. Berdasarkan data yang diperoleh, skor tertinggi yang memiliki responden adalah 8 sampai 12 jam dalam satu minggu. Skor sedang yang dimiliki responden adalah 4 sampai 7 jam dalam satu minggu. Sementara, skor terendah adalah 1 sampai 3 jamdalam satu minggu. Persentase responden berdasarkan durasi mendengarkan tersaji pada Tabel 6 di bawah ini:

Tabel 6 Jumlah dan persentase responden berdasarkan frekuensi mendengarkan radio

\begin{tabular}{lccc}
\hline Durasi & Jam/Hari & $\mathrm{n}$ & $\%$ \\
\hline Rendah & 1-3/hari & 19 & 38 \\
Sedang & 4-7/hari & 20 & 40 \\
Tinggi & 8-12/hari & 11 & 22 \\
\hline Jumlah & & 50 & 100 \\
\hline
\end{tabular}

Berdasarkan Tabel 6, tingginya tingkat akses terhadap radio di kalangan responden diikuti dengan beragamnya waktu yang dialokasikan responden dalam mendengarkan. Sebanyak $38 \%$ responden mengalokasikan 1-3 jam waktunya dalam satu hari untuk mendengarkan radio, $40 \%$ responden mengalokasikan waktunya selama 4-7 jam, dan $22 \%$ responden mendengarkan radio lebih dari tujuh jam dalam satu hari. Hal ini signifikan bahwa pendengar banyak mengalokasikan waktunya untuk mendengarkan radio komunitas.

“..saya ya paling lama denger radio sekitar 6 jam kaliya neng biasanya sambil kerja atau ya sambil ngopi gitu. Tapi kalo misalnya materinya lagi tentang pertanian atau tentang harga pasar gitu-gitu kadang bisa seharian dengar jadi informasi dapet, hiburan juga dapet gitu neng.." (U, laki-laki, 50 tahun)

\section{Tingkat Kepuasan berdasarkan Kebutuhan Informasi}

Persentase jumlah pendengar radio komunitas berdasarkan pada terpenuhinya kebutuhan informasi tergolong sedang, yaitu 70 persen dan sebanyak 30 persen responden yang pemenuhan kebutuhan informasinya tergolong tinggi. Hal tersebut disebabkan banyak dari responden hanya mendengarkan pilihan program siaran radio yang didominasi musik dan hiburan. Sebagaimana diketahui, baik informasi formal maupun informal, disiarkan disela-sela program siaran yang memang sangat mendominasi program acara Radio Komunitas Remaja FM. Seperti halnya informasi mengenai pendidikan dan kesehatan disiarkan sesuai dengan kebutuhan pendengarnya pada waktu tertentu. Persentase responden berdasarkan kebutuhan informasi tersaji pada Tabel 7.

Tabel 7 Jumlah dan persentase responden berdasarkan kepuasan kebutuhan informasi

\begin{tabular}{ccc}
\hline Kebutuhan Informasi & $\mathrm{n}$ & $\%$ \\
\hline Rendah & 0 & 0 \\
Sedang & 35 & 70 \\
Tinggi & 15 & 30 \\
\hline Jumlah & 50 & 100 \\
\hline
\end{tabular}

Tingkat kepuasan pendengar menurut kebutuhan informasi dari responden yang ada di Desa Majasari relatif sedang sebesar $70 \%$. Responden dengan kategori tinggi atau menjawab sangat setuju sebesar $30 \%$ yang artinya responden menganggap radio komunitas Remaja FM memenuhi kebutuhan informasi yang dicari oleh responden. Dalam hal ini berarti banyak dari responden yang menjawab setuju hingga sangat setuju bahwa adanya Radio Komunitas Remaja FM di Desa Majasari memberikan informasi terkini mulai dari informasi mengenai pertanian, kesehatan, pendidikan, budaya dan informasi mengenai Desa Majasari.

\section{“..sangat membantu mbak, apalagi kalau musim hama jadi kalo ada masalah ya saya langsung tanya ke penyiar langsung sms gitu. Biasanya juga suka ada yang dari dinas pertaniannya jadi yg ngasih materi gitu nah nanya ke beliau jadi ya lumayan kebantu lah bisa tanya-tanya sama yang laen juga gitu”" (SN, laki- laki, 48 tahun)}

Peneliti membuat kategori rendah sedang tinggi dalam variabel tingkat kepuasan pendengar dengan penentuan skor merujuk pada hasil yang didapat responden keseluruhan di lapang. 


\section{Tingkat Kepuasan berdasarkan Kebutuhan Kontak Sosial}

Kepuasan selanjutnya diukur dalam bentuk terpenuhinya kebutuhan kontak sosial dalam lingkungan sosial. Berdasarkan data yang diperoleh pada Tabel 13 sebanyak 44 persen responden memiliki pemenuhan kebutuhan kontak sosial yang tergolong rendah. Hal tersebut disebakan banyak dari pendengar hanya mendengarkan materi siaran atau pertanyaan dan keluhan dari pendengar lain yang akan dijawab oleh pemateri. Banyak dari mereka jarang bertukar pikiran bahkan saling berbagi informasi secara tatap muka. Persentase responden berdasarkan kebutuhan kontak sosial tersaji pada Tabel 8 di bawah ini:

Tabel 8 Jumlah dan persentase responden berdasarkan kepuasan kebutuhan kontak sosial

\begin{tabular}{ccc}
\hline Kebutuhan Kontak Sosial & $\mathrm{N}$ & $\%$ \\
\hline Rendah & 22 & 44 \\
Sedang & 13 & 26 \\
Tinggi & 15 & 30 \\
\hline Jumlah & 50 & 100
\end{tabular}

Tingkat kepuasan pendengar menurut kebutuhan kontak sosial dari responden yang ada di Desa Majasari relatif rendah yaitu sebesar $44 \%$. Responden dengan kategori sedang sebesar $26 \%$. Responden dengan kategori tinggi sebesar 30 persen. Dalam hal ini berarti banyak responden yang menjawab tidak setuju untuk bertemu langsung dengan pendengar lain atau penyiar, lebih banyak dari mereka hanya mendengarkan langsung dan bertanya via sms/telepon daripada kontak langsung dengan pendengar lain.

“..sangat membantu mbak, apalagi kalau musim hama jadi kalo ada masalah ya saya langsung tanya ke penyiar langsung sms gitu. Biasanya juga suka ada yang dari dinas pertaniannya jadi yg ngasih materi gitu nah nanya ke beliau jadi ya lumayan kebantu lah bisa tanya-tanya sama yang laen juga gitu” (SN, laki-laki, 48 tahun)

\section{Hubungan Umur Responden dengan Frekuensi Mendengarkan Radio Komunitas}

Karakteristik responden atau karakteristik pendengar yang mendengarkan Radio Komunitas Remaja FM memiliki tiga indikator yaitu umur, tingkat pendidikan, dan kepemilikan media massa. Hubungan umur responden dengan frekuensi mendengarkan radio dilihat dari berapa banyak hari yang dialokasikan responden untuk mendengarkan radio.

Mayoritas pendengar dengan umur kategori rendah atau dibawah 43 tahun mendengarkan radio pada kategori tinggi atau sebanyak lima hingga tujuh kali per minggu yaitu sebesar 81,2 persen, dan sisanya berada pada kategori frekuensi mendengarkan pada tingkat sedang sebesar 12,5 persen dan kategori rendah sebanyak 6,2 persen. Pendengar dengan umur kategori sedang atau sekitar umur 44 hingga 54 tahun mendengarkan radio pada tingkat tinggi yaitu sebesar 72,2 persen, dan sisanya pada kategori sedang atau mendengarkan tiga sampai empat kali seminggu sebanyak 27,8 persen. Pendengar dengan umur kategori tinggi atau diatas 54 tahun mendengarkan radio pada tingkat sedang yaitu sebanyak 50 persen, sisanya berada pada kategori tinggi dan rendah sebesar 25 persen. Keduanya berkorelasi dengan $p$ value 0.001 dan koefisien korelasi sebesar -0.463 , yang artinya keduanya memiliki hubungan negatif dan signifikan antara umur dengan frekuensi mendengarkan, tetapi hubungan yang ada bersifat tidak searah.

\section{Hubungan Umur Responden dengan Durasi Mendengarkan Radio Komunitas}

Hubungan umur responden dengan durasi mendengarkan radio dilihat dari berapa lama responden mendengarkan radio.

Mayoritas pendengar dengan umur kategori rendah mendengarkan radio pada tingkat sedang sebanyak empat hingga tujuh jam per hari yaitu sebesar 43,8 persen, dan sisanya berada pada kategori durasi mendengarkan pada tingkat rendah sebesar 25 persen dan kategori tinggi sebanyak 31,2 persen. Pendengar dengan umur kategori sedang mendengarkan radio pada tingkat sedang yaitu sebesar 50 persen, sisanya pada kategori rendah sebanyak 38,9 persen dan pada kategori tinggi sebanyak 11,1 persen. Pendengar dengan umur kategori tinggi mendengarkan radio pada tingkat rendah atau selama satu hingga tiga jam per hari yaitu sebanyak 50 persen, sisanya berada pada kategori sedang dan tinggi sebesar 25 persen.

Keduanya berkorelasi dengan $\mathrm{p}$ value 0.228 dan koefisien korelasi sebesar -0.174 , yang artinya keduanya memiliki hubungan yang negatif dan tidak signifikan. Keduanya tidak signifikan dan menunjukkan angka 0,228 atau lebih besar dari nilai $\alpha$ $(0,05)$ itu berarti tua atau muda umur responden tidak 
berhubungan dengan lamanya mendengarkan radio komunitas. Hal tersebut menunjukkan semakin tua umur seorang responden maka semakin rendah frekuensi dalam mendengarkan radio komunitas, begitupun sebaliknya.

\section{Hubungan Tingkat Pendidikan Responden dengan Frekuensi Mendengarkan Radio Komunitas}

Hubungan tingkat pendidikan dengan frekuensi mendengarkan adalah untuk mengetahui tingkatan pendidikan responden dan berapa banyak hari yang dialokasikan untuk mendengarkan radio.

mayoritas pendengar dengan tingkat pendidikan kategori rendah atau yang tidak bersekolah dan tamatan SD mendengarkan radio pada tingkat tinggi sebanyak lima hingga tujuh kali seminggu yaitu sebesar 52 persen, dan sisanya berada pada kategori frekuensi mendengarkan pada tingkat sedang sebesar 36 persen dan kategori rendah sebanyak 12 persen. Pendengar dengan tingkat pendidikan kategori sedang atau mengenyam pendidikan SMP dan SMA mendengarkan radio pada tingkat tinggi yaitu sebesar 70,8 persen, dan sisanya pada kategori sedang sebanyak 20,8 persen dan kategori rendah sebesar 8,3 persen. Pendengar dengan tingkat pendidikan kategori tinggi atau mengikuti perguruan tinggi mendengarkan radio pada tingkat sedang yaitu sebanyak 100 persen. Tingkat Pendidikan responden berhubungan tidak nyata dengan frekuensi mendengarkan pada siaran radio komunitas. Keduanya berkorelasi dengan $\mathrm{p}$ value 0.350 dan koefisien korelasi sebesar 0.135 , yang artinya keduanya memiliki hubungan yang tidak nyata dan tidak signifikan dengan signifikankasi menunjukkan angka 0,350 .

\section{Hubungan Tingkat Pendidikan Pendengar dengan Durasi Mendengarkan Radio Komunitas}

Hubungan tingkat pendidikan dengan frekuensi mendengarkan adalah untuk mengetahui tingkatan pendidikan responden dan berapa lama waktu yang dialokasikan untuk mendengarkan radio.

Mayoritas pendengar dengan tingkat pendidikan kategori rendah mendengarkan radio pada tingkat sedang sebesar 40 persen, dan sisanya berada pada kategori durasi mendengarkan pada tingkat rendah sebesar 36 persen dan kategori tinggi sebanyak 24 persen. Pendengar dengan tingkat pendidikan kategori sedang mendengarkan radio pada tingkat sedang yaitu sebesar 41,7 persen, dan sisanya pada kategori rendah sebanyak 37,5 persen dan kategori tinggi sebesar 20,8 persen. Pendengar dengan tingkat pendidikan kategori tinggi mendengarkan radio pada tingkat rendah yaitu sebanyak 100 persen. Keduanya berkorelasi dengan $p$ value 0.613 dan koefisien korelasi sebesar -0.073, yang artinya keduanya memiliki hubungan yang negatif dan tidak signifikan. Nilai tersebut menunjukkan terdapat hubungan yang rendah antara umur dengan durasi mendengarkan, hubungan bersifat tidak searah. Keduanya tidak signifikan dan menunjukkan angka 0,613 .

\section{Hubungan Jenis Pekerjaan dengan Frekuensi Mendengarkan Radio Komunitas}

Hubungan jenis pekerjaan dengan frekuensi mendengarkan adalah untuk mengetahui jenis pekerjaan responden dan berapa banyak hari yang dialokasikan untuk mendengarkan radio.

Jenis pekerjaan menggunakan skala nominal untuk dilihat korelasi atau hubungannya dengan frekuensi mendengarkan mendengarkan radio komunitas yang diolah dengan menggunakan uji korelasi Chi Square. Hasil uji hubungan karakteristik responden yaitu Jenis Pekerjaan dengan frekuensi mendengarkan radio komunitas dapat dilihat pada Tabel 9 di bawah ini:

Tabel 9 Nilai Tabulasi Silang Chi Square untuk Jenis Pekerjaan dan Frekuensi mendengarkan radio komunitas

\begin{tabular}{lrrc}
\hline & & & $\begin{array}{c}\text { Asymptotic } \\
\text { Significance } \\
\end{array}$ \\
& Value & Df & (2-sided) \\
\hline Pearson Chi-Square & $8,990^{\text {a }}$ & 8 &, 343 \\
Likelihood Ratio & 10,664 & 8 &, 221 \\
Linear-by-Linear &, 965 & 1 &, 326 \\
Association & 50 & & \\
\hline N of Valid Cases & &
\end{tabular}

Berdasarkan Tabel 9 nilai uji sebagaimana ditunjukan pada Tabel, frekuensi mendengarkan radio komunitas hari per satu minggu tidak berhubungan dengan status pekerjaan responden. Nilai uji non parametik Chi Square 0.343 dan 0.221 . Hal tersebut menunjukkan status pekerjaan apapun yang dimiliki responden, tidak menentukan pada banyak dan lamanya mereka mendengarkan radio komunitas. 


\section{Hubungan Jenis Pekerjaan dengan Durasi Mendengarkan Radio Komunitas}

Hubungan jenis pekerjaan dengan durasi mendengarkan adalah untuk mengetahui jenis pekerjaan responden dan berapa lama waktu yang dialokasikan untuk mendengarkan radio.

Hasil uji hubungan karakteristik responden yaitu Jenis Pekerjaan dengan durasi mendengarkan radio komunitas dapat dilihat pada Tabel 10 di bawah ini:

Tabel 10 Nilai Tabulasi Silang Chi Square untuk Jenis Pekerjaan dan Durasi mendengarkan Radio Komunitas

\begin{tabular}{|c|c|c|c|}
\hline & Value & $\mathrm{df}$ & $\begin{array}{r}\text { Asymptotic } \\
\text { Significance } \\
\text { (2-sided) }\end{array}$ \\
\hline Pearson Chi-Square & $7,547^{\mathrm{a}}$ & 8 &, 479 \\
\hline Likelihood Ratio & 8,142 & 8 & ,420 \\
\hline $\begin{array}{l}\text { Linear-by-Linear } \\
\text { Association }\end{array}$ & ,498 & 1 & ,480 \\
\hline $\mathrm{N}$ of Valid Cases & 50 & & \\
\hline
\end{tabular}

Berdasarkan nilai uji sebagaimana ditunjukan pada Tabel, durasi mendengarkan radio komunitas perhari tidak berhubungan dengan status pekerjaan responden. Nilai koefisien korelasi uji non parametik Chi Square 0.479 dan 0.420 . Hal tersebut menunjukkan status pekerjaan apapun yang dimiliki responden, tidak menentukan pada lamanya mereka mendengarkan radio komunitas.

\section{Hubungan Kepemilikan Media Massa dengan Frekuensi Mendengarkan Radio Komunitas}

Hubungan kepemilikan media massa dengan frekuensi mendengarkan adalah untuk mengetahui responden dengan kepemilikan media massa rendah, sedang atau tinggi dengan berapa banyak hari yang dialokasikan untuk mendengarkan radio. Mayoritas pendengar dengan kepemilikan media massa kategori rendah atau hanya memiliki satu media massa mendengarkan radio pada tingkat tinggi yaitu sebesar 50 persen, dan sisanya berada pada kategori frekuensi mendengarkan pada tingkat sedang sebesar 41,7 persen dan kategori rendah sebanyak 8,3 persen. Pendengar dengan kepemilikan media massa kategori sedang atau memiliki dua sampai tiga macam media mendengarkan radio pada tingkat tinggi yaitu sebesar 64,7 persen, dan sisanya pada kategori sedang sebanyak 23,5 persen dan kategori rendah sebesar 11,8 persen. Pendengar dengan kepemilikan media massa kategori tinggi atau memiliki lebih dari tiga media mendengarkan radio pada tingkat sedang dan tinggi yaitu sebanyak 50 persen.

Keduanya berkorelasi dengan $p$ value 0.655 dan koefisien korelasi sebesar 0.065, yang artinya keduanya memiliki hubungan, namun korelasi diantara keduanya tidak nyata dan tidak signifikan. itu berarti kepemilikan media massa responden tidak berhubungan dengan banyaknya hari yang responden alokasikan untuk mendengarkan radio komunitas.

\section{Hubungan Kepemilikan Media Massa dengan Durasi Mendengarkan Radio Komunitas}

Hubungan kepemilikan media massa dengan durasi mendengarkan adalah untuk mengetahui responden dengan kepemilikan media massa rendah, sedang atau tinggi dengan berapa lama waktu yang dialokasikan untuk mendengarkan radio.

mayoritas pendengar dengan kepemilikan media massa kategori rendah mendengarkan radio pada tingkat sedang yaitu sebesar 41,7 persen, dan sisanya berada pada kategori frekuensi mendengarkan pada tingkat rendah sebesar 33,3 persen dan kategori tinggi sebanyak 25 persen. Pendengar dengan kepemilikan media massa kategori sedang mendengarkan radio pada tingkat sedang yaitu sebesar 41,2 persen, dan sisanya pada kategori rendah sebanyak 35,3 persen dan kategori tinggi sebesar 23,5 persen. Pendengar dengan kepemilikan media massa kategori tinggi mendengarkan radio pada tingkat rendah yaitu sebesar 75 persen dan sisanya kategori sedang yaitu 25 persen. Keduanya berkorelasi dengan $\mathrm{p}$ value 0.301 dan koefisien korelasi sebesar -0.149. Nilai tersebut menunjukkan terdapat hubungan yang rendah antara dan bersifat tidak searah itu berarti kepemilikan media massa responden tidak berhubungan dengan lamanya mendengarkan radio komunitas.

\section{Hubungan Frekuensi Mendengarkan dengan Kepuasan Kebutuhan Informasi}

Mendengarkan radio komunitas berkaitan dengan seberapa sering pendengar mendengarkan radio komunitas. Akses pendengar terhadap radio tentu mempunyai kesan dan alasan tersendiri mengapa 
pendengar selalu atau bahkan tidak mendengarkan radio. Kesan dan alasan inilah yang akan menentukan apakah pendengar merasa puas dengan siaran radio komunitas atau tidak. Mayoritas pendengar dengan frekuensi mendengarkan pada kategori rendah atau mendengarkan radio sebanyak satu hingga dua kali per minggu memenuhi kebutuhan informasi pada tingkat sedang yaitu sebesar 60 persen, dan sisanya berada pada kategori tinggi sebesar 40 persen. Pendengar dengan frekuensi mendengarkan pada kategori sedang atau mendengarkan radio sebanyak tiga sampai empat hari per minggu memenuhi kebutuhan informasi pada kategori sedang yaitu sebesar 86,7 persen, dan sisanya pada kategori tinggi sebanyak 13,3 persen. Pendengar dengan frekuensi mendengarkan pada kategori tinggi atau mendengarkan radio sebanyak lima sampai tujuh hari per minggu memenuhi kebutuhan informasi pada tingkat sedang yaitu sebesar 63,3 persen, dan sisanya pada kategori tinggi yaitu sebanyak 36,7 persen.

Keduanya berkorelasi dengan $p$ value 0.335 dan koefisien korelasi sebesar 0.139, yang artinya keduanya memiliki hubungan, namun korelasi di antara keduanya tidak nyata dan tidak signifikan.

\section{Hubungan Frekuensi Mendengarkan dengan Kepuasan Kebutuhan Kontak Sosial}

Mendengarkan radio komunitas berkaitan dengan seberapa sering pendengar mengalokasikan waktunya untuk mendengarkan radio komunitas. Akses pendengar terhadap radio tentu mempunyai kesan dan alasan tersendiri mengapa pendengar selalu atau bahkan tidak mendengarkan radio. Kesan dan alasan inilah yang akan menentukan apakah pendengar merasa puas dengan siaran radio komunitas atau tidak. Mmayoritas pendengar dengan frekuensi mendengarkan pada kategori rendah memenuhi kebutuhan kontak sosial pada tingkat rendah yaitu sebesar 60 persen, dan sisanya berada pada kategori sedang sebesar 40 persen. Pendengar dengan frekuensi mendengarkan pada kategori sedang memenuhi kebutuhan kontak sosial pada kategori rendah yaitu sebesar 40 persen, dan sisanya pada kategori sedang sebanyak 26,7 persen dan pada kategori tinggi sebanyak 33,3 persen. Pendengar dengan frekuensi mendengarkan pada kategori tinggi memenuhi kebutuhan kontak sosial pada tingkat rendah yaitu sebesar 43,3 persen, sisanya pada kategori sedang yaitu sebanyak 23,3 persen dan pada kategori tinggi sebanyak 33,3 persen.

Keduanya berkorelasi dengan $\mathrm{p}$ value 0.543 dan koefisien korelasi sebesar 0.088, yang artinya keduanya memiliki hubungan, namun korelasi di antara keduanya tidak nyata dan tidak signifikan.

Keterdedahan pada siaran radio tidak sepenuhnya berhubungan tidak nyata dengan tingkat kepuasan pendengar radio komunitas. Hal tersebut karena frekuensi mendengarkan tidak berhubungan dengan tingkat kepuasan pendengar pada Radio Komunitas Remaja FM. Hal tersebut menunjukkan bahwa sering atau tidaknya responden mendengarkan radio, tidak berhubungan dengan tingkat kepuasan responden dalam hal terpenuhinya kebutuhan akan informasi dan kebutuhan kontak sosial.

\section{SIMPULAN DAN SARAN}

\section{Simpulan}

Berdasarkan hasil penelitian dapat disimpulkan bahwa terdapat hubungan yang signifikan antara umur responden dengan frekuensi mendengarkan radio. Secara garis besar, kesimpulan yang dapat ditarik dalam penelitian adalah pertama, karakteristik responden yaitu umur, tingkat pendidikan, jenis pekerjaan, dan kepemilikan media massa, hanya umur responden yang memiliki hubungan signifikan dengan frekuensi mendengarkan radio. Kedua, tingkat keterdedahan pendengar, Frekuensi mendengarkan radio ada pada kategori tinggi dan durasi mendengarkan radio berada pada kategori sedang, karena pendengar yang mayoritas adalah warga Desa Majasari hanya mengakses satu saluran radio yaitu Radio Komunitas Remaja FM yang mereka butuhkan untuk mendapatkan suatu informasi atau ingin mendapatkan jawaban dari masalah pertanian mereka. Ketiga, tingkat kepuasan pendengar dalam memperoleh informasi masuk dalam kategori sedang yang berarti banyak responden yang menjawab setuju atau cukup puas dengan informasi yang didapat dari radio. Sedangkan pada kepuasan kebutuhan kontak sosial termasuk dalam kategori rendah, yang berarti responden lebih sering mendengarkan langsung daripada bertemu langsung dengan pendengar lain atau penyiar. Keempat, hubungan karakteristik pendengar Radio Komunitas Remaja FM dengan tingkat keterdedahan pendengar, dari tiga indikator karakteristik pendengar yang diuji hanya terdapat satu 
indikator yang memiliki hubungan yang signifikan, yaitu, indikator umur pendengar dengan frekuensi mendengarkan. Kemudian, hubungan dua indikator lainnya, yaitu tingkat pendidikan dan kepemilikan media massa dengan durasi dan frekuensi mendengarkan tidak memiliki hubungan yang signifikan. Hubungan tingkat keterdedahan pendengar dengan tingkat kepuasan pendengar tidak memiliki hubungan yang signifikan. Tingkat kepuasan dalam mendengarkan radio komunitas cenderung tidak memperhatikan tingkat pendidikan atau dapat dikatakan bahwa mendengarkan radio komunitas bersifat bebas tidak memiliki tingkatan khusus untuk mendengarkannya.

\section{Saran}

Berdasarkan hasil penelitian, maka dapat ditarik beberapa hal yang dapat dijadikan masukan atau saran, diantaranya: (1) Bagi pengelola radio komunitas untuk lebih giat lagi menghimpun berbagai program siaran dan informasi yang sesuai dengan kebutuhan pendengarnya. Frekuensi dan durasi pendengar mendengarkan radio komunitas tergolong tinggi menjadikan radio komunitas memiliki potensi dalam mengembangkan komunitasnya melalui program acara yang sesuai dengan kebutuhan anggota komunitasnya. (2) Bagi lembaga yang memiliki wewenang di bidang pengembangan penyiaran, sebaiknya mendukung dan memperkaya perkembangan radio komunitas agar dapat bermanfaat antar komunitas dengan komunitas lainnya.

\section{DAFTAR PUSTAKA}

Atika. 2013. Pola penggunaan Radio Komunitas Untuk Pemenuhan Kebutuhan Informasi Petani. [thesis]. Bogor (ID): Institut Pertanian Bogor.

[BPS] Badan Pusat Statistik Kabupaten Indramayu. 2017. Kabupaten Sleman dalam Angka [internet]. [14 Januari 2018].

https://indramayukab.bps.go.id/

Dewi AS. 2011. Radio Komunitas dan Disaster Risk Reduction: Studi Kasus Radio Lintas Merapi Di Klaten Jawa Tengah Dan Radio Angkringan di Yogyakarta. Jurnal Sosiologi DeliMa. [internet]. [dikutip tanggal 12 Maret 2014]. 27(2): 1781-188. Dapat diunduh dari: http://lppm.uns.ac.id/kinerja/files/jurnal/lppmjurna 1201114122013175752 pdf\#page $=97$

Fraser C, Estrada I. 2001. Buku Panduan Radio Komunitas. Jakarta:UNESCO Jakarta Office.
Gazali E. 2002. Penyiaran Alternatif tapi Mutlak: Sebuah Acuan tentang Penyiaran Publik dan Komunitas. Jakarta (ID): Penerbit Jurusan Ilmu Komunikasi FISIP UI

Ismahfudi, MH, 2007. Radio Komunitas: Media Pemberdayaan Perempuan. Dlm Jurnal Studi Gender dan Islam. 5(1). Jogjakarta(ID) : PSW UIN Sunan Kalijaga Jogjakarta.

Nurmayanti AW. 2012. Hubungan Perilaku Komunikasi Dengan Pemahaman Petani Terhadap Fungsi Radio Komunitas (Kasus Radio Komunitas Petani Trisna Alami, DesaKaliagung,Kecamatan Sentolo,Kabupaten Kulon Progo, Provinsi D.I Yogyakarta). [skripsi]. Bogor (ID): Institut Pertanian Bogor.Nazara S, Rahayu SK. 2013. Program Keluarga Harapan (PKH): Program Bantuan Dana Tunai Bersyarat di Indonesia. Research Brief. TNP2K (42).

Rachmiatie A. 2005. Keberadaan radio komunitas sebagai eskalasi demokratisasi komunikasi pada komunitas pedesaan di Jawa Barat. Jurnal Mediator. [internet]. [13 Oktober 2016]. 6(2). Dapat diunduh dari : http://ejournal.unisba.ac.id/index.php/mediator/arti cle/view/1190/744

Rachmiatie A. 2007. Radio Komunitas Eskalasi Demokratisasi Komunikasi. Bandung (ID): PT Remaja Rosdakarya.

[RI] Undang-Undang Republik Indonesia Nomor 20 Tahun 2003 tentang Pendidikan

[RI] Undang-Undang Republik Indonesia Nomor 32 Tahun 2002 tentang Peny;

Rubin AM. 2005. The Uses. _ ratifications Perspective Of Media Efects. Dalam: Bryant J, Zillman D, editor: Media effects: Advances in theory and research. Hal 525-548. London [ENG]: Lawrence Erlbaum Associates.

Silviana, M. 2015. Partisipasi, Keterdedahan dan Kepuasan Pendengar Radio Komunitas R-One Kecamatan Bojong Gede Kabupaten Bogor [Skripsi]. Bogor (ID) : Fakultas Ekologi Manusia, Institut Pertanian Bogor.

Sudibyo. 2004. Ekonomi Politik Media Penyiaran. Yogyakarta: LKIS

Tede M. 2012. Pengaruh program siaran Radio Pertanian Ciawi bagi pendengarnya (Kasus pendengar di Desa Cileungsi, Kecamatan Ciawi, Kabupaten Bogor). [skripsi]. Bogor (ID): Institut Pertanian Bogor.

Tripambudi S. 2011. Radio komunitas sebagai media alternatif untuk pemberdayaan masyarakat. Jurnal Ilmu Komunikasi. [internet]. [02 Desember 2016]. 9(3). Dapat diunduh dari : http://repository.upnyk.ac.id/2518/1/Sgit_Tri.pdf 